\title{
ACADEMIC PERFORMANCE OF EMOTIONALLY STABLE SECONDARY SCHOOL PRINCIPALS
}

\author{
Syed Kamran Ali Shah \\ Ph.D. Scholar, \\ Division of Education, University of Education \\ Punjab, Pakistan \\ Email: ravian7985@gmail.com

\section{Irum Muzammil} \\ Ph.D. Scholar, \\ Division of Education, University of Education \\ Punjab, Pakistan \\ Email: irumzzzz7@gmail.com \\ Muqaddas Butt \\ Assistant Professor, \\ Division of Education, University of Education \\ Punjab, Pakistan \\ Email: muqaddas.butt@ue.edu.pk
}

\begin{abstract}
This study aimed at exploring the relationship between emotionally stable school principals and their academic performance in terms of student academic achievement. A sample of 32 secondary school principals and 238 teachers working in Ffederal Ggovernment Eeducational Iinstitutions (FGEIs) was selected using a random sampling technique. Data collection was carried out using two adapted questionnaires of Eysenck Personality Inventory (1967) and Stronge (2011). SPSS (21.0) was used for data analysis. The study revealed that the majority of emotionally stable secondary school principals focus to improve the overall learning environment of the school. They are found to be positively correlated with their academic performance. The study recommends that secondary school principals should be provided proper awareness about performance standards of school principals. Principals should be encouraged to adopt positive personality traits of emotional stability.
\end{abstract}

\section{KEYWORDS}

Emotionally stable, neurotic, academic performance, secondary school principals, relationship 


\section{INTRODUCTION}

The school principal plays a significant role in achieving organizational objectives. $\mathrm{He} /$ she holds the responsibility of supporting and assisting the school faculty. The principal works as a team leader and provides directions and coordination to the whole team of an educational institution. He/she focuses upon the better quality of the teaching-learning process and maintains high standards of teaching for the education of students within a school. The principal is responsible for the provision good learning environment for the growth of the students. He/she plays the role of supervisor and facilitator for the faculty members. He/she keeps up-to-date knowledge of modern educational concepts and teaching techniques and provides guidelines to the faculty and the students accordingly. In this way, the principal plays a vital role in quality teaching, policy implementation, better command and control, and guidance and evaluation for both the teachers and the students of the school (Gurr, 2005). The principal provides a detailed schedule of academic activities and life learning skills to the students and guides them to achieve the goals and objectives. He/she discusses discipline issues with the faculty members and provides them guidance on how to resolve such issues. He/she maintains the student and staff data and provides details to the higher administration as and when required. He/she focuses upon the overall academic and non-academic improvement of the educational institution (Ali, 2011).

The principal should hold a close and healthy relationship with the parents and guardians of the students. He/she maintains the updated record of students' academic achievements. He/she focuses upon the overall personality development of students and holds continuous contact with the parents. In this way, he/she performs his duties in close association with the other stakeholders. The principal is responsible for the maintenance of all kinds of financial accounts related to students, library, laboratory, examination, and building, etc. He/she should have deep knowledge related to financial management. The principal maintains high standards of cleanliness of school buildings through sanitary staff. He/she provides the necessary materials and instructions so that they may be able to complete the task of cleanliness of the school (Clark, Martorell \& Rockoff 2009). The principal has to keep in contact with different departments and organizations police and other law enforcement agencies, health and disaster management authority, etc. He/she has to talk to the media in different situations related to academic and other activities of the institution. To cope with all this, the principal should have excellent written and oral communication skills. He/she submits reports upon the achievements of the students and overall progress of the institution to the higher authorities (Oyegoke, 2012).

In this study, the researchers investigated the academic performance of emotionally stable secondary school principals. The study was conducted in Federal Government Educational Institutions (FGEI's). These institutions are working throughout Pakistan 
and focus on providing education, which is based on quality and innovation, to its students. Mostly the students in these schools are the wards of serving or retired army persons and the civilian residents of cants. FGEI's aims to groom the students to become useful citizens of Pakistan. The secondary school principals play a vital role to achieve these targets of FGEI's. This study focused upon the determining personality trait of emotional stability of the secondary school principals of FGEI's and explored the relationship of emotional stability with their academic performance. Other chains of educational institutions at the national and local levels would benefit from this study. This study would also help the school leadership in improving their academic performance. Future researchers may research other dimensions of performance which include managerial and human relationship performance etc.

\section{LITERATURE REVIEW}

\section{Personality Traits}

Personality traits are such capabilities of an individual that are explicitly related to him or her only. These are commonly exhibited through the behaviour, personality, and feeling of an individual. Eysenck (1916-97) categorized the personality traits by using the method of factor analysis. Initially, Eysenck has based on a supposition that personality has two super traits. He categorized that human personality as either extrovert/introvert or emotionally stable/neurotic. He further assumed that extrovert people are friendly and highly receptive while introvert people are calm and less enthusiastic. Similarly, the emotional people are fair and quiet whereas the neurotic people are worried and feeble. According to Eysenck, a combination of extroversion and neurotic super traits generates variation among the personality of an individual. The people may be highly receptive and angry if they have a high level of extroversion and neurotic super traits. On the other hand, if they have a low level of extroversion and neurotic super traits, they may be optimistic and sociable.

There are different methods used to measure personality. Eysenck presented a technique to calculate the super traits of extroversion / introversion and emotional stability/neuroticism. This technique is known as Eysenck's personality inventory (EPI). It contains a simple Yes-No format to reply to the items to identify extroversion / introversion and emotional stability/neuroticism scores of an individual. The EPI Performa provides the following types of scores:

1. The lie score: It tells about the extent to which the respondent has tried to show himself/herself good. It ranges from 0 to 9.

2. The N score: This score tells us about the emotional stability/ neuroticism of the respondent. Its values vary from 0 to 24 . The following table 1 shows major characteristics of personality traits of emotional stability and neuroticism. 


\begin{tabular}{ccc}
\hline Table 1: & Major Characteristics of Emotionally Stable and Neurotic Principals \\
\hline Sr. No & Personality Trait & Major Characteristics \\
\hline 01 & Emotional Stability & Controlled, Reliable, Lively, Calm, Peaceful \\
02 & Neuroticism & Moody, Anxious, Rigid, Reserved, Touchy \\
\hline
\end{tabular}

\section{Performance}

Simply saying performance is such a procedure which is adopted on the instructions of some senior officers and for the betterment of the organization and other stakeholders. It includes all such activities that have a significant role in achieving the objectives of an organization (Campbell, 2010).

\section{Performance Measurement}

It is such a method in which the ability and competency of an individual or organization are calculated. It tells us about the working of an organization and the achievement of organizational objectives. It is a well-defined and permanent process in which the output of an individual or organization is assessed. The performance measurement provides a basis to identify issues and challenges which create a hurdle in achieving the targets. Moreover, it helps in future planning for the performance improvement of an organization.

\section{Uniform Performance Standards for Principals}

These are such specific skilled duties which a principal is expected to perform on regular basis. These standards help us in data collection regarding the performance of school principals. The major focus of these standards is upon enthusiasm, vision, adjustability, and adaptability of school principals. These help the principals to improve their performance. Virginia Department of Education, Virginia (January 10, 2020) has stated seven such standards which are helpful to explore and improve the performance of schools. In the following paragraphs these standards have been stated shortly:

\section{Provision of Coaching and Guidance to all stakeholders}

The school principal facilitates the students to achieve academic progress. He follows a shared vision of leadership for the improvement of the school. He provides professional coaching and guidance to all the concerned including faculty, students, parents, and others.

\section{Managing School Environment}

A positive, safe, and learning-based environment of school help to achieve the academic success of students. The principal should promote a healthy environment in school. He / She is responsible to facilitate the students by providing them a good learning environment to achieve their academic progress. 


\section{Faculty Management}

The faculty members play a significant role to achieve academic excellence and organizational objectives. The principal should focus upon the best utilization of the faculty members keeping their attitude, aptitude, and professional skills in view. In this way, the school principal can maximize the output of the teaching-learning process and may attain the academic excellence of students.

\section{Managing Official Correspondence}

The principal office receives certain policy letters which higher authorities desire to implement for the betterment of school and students. Moreover, senior administration needs essential data regarding the faculty and the students for future planning. In this way, the role of the principal office is very important. The principal is responsible for the management of all correspondence. He/she should efficiently inform the faculty and the students regarding policies issued by higher authorities. Accordingly $\mathrm{He} / \mathrm{she}$ should provide necessary data to senior administration for the purpose of future planning.

\section{Human Relationship Management}

The principal is the key person who has to interact with all stakeholders of the school. This is his / her duty to utilize capabilities and communication skills to create a good working relationship with all stakeholders. This may improve the overall environment of the school and result in the academic excellence of the students.

\section{Developing Professional Skills}

The principal should engage himself / herself in the process of continuous professional development. $\mathrm{He} /$ she should focus on contributing to the profession. $\mathrm{He} /$ she should represent high professional standards. $\mathrm{He} /$ she focuses on professional ethics while interacting with all stakeholders. In this way he/she may be able to improve student learning outcomes and to enhance academic excellence in the school.

\section{Student Learning Expansion}

The leadership behaviour of the school principal increases the academic progress of the students. So he/she should focus to follow all the above-mentioned performance standards. This may help him / her to achieve organizational targets and to improve the quality of education. This may ultimately result in the academic excellence of the learners.

\section{Academic Performance of School Principals}

An indirect link is present between the performance of school principals and student progress. The principal influences the teachers by his/her professional capabilities and this impacts student learning within classrooms. So the principal enhances student 
learning outcomes through his/her professional skills. The academic performance of the school principals can be monitored by checking the following activities (Stronge, 2011).

The principal develops, executes, and checks different plans for improving the school in close consultation with all stakeholders.

The principal makes decisions regarding different measures to increase student progress by using research-based techniques.

The principal shares student academic progress output with other stakeholders for improvement.

The principal provides learning material to teachers and ensures the availability of sufficient teaching faculty.

The principal makes frequent classroom visits to encourage students to work hard and closely monitors the academic progress of students.

The principal motivates teachers to prepare a lesson plan, guides teachers about modern teaching techniques, encourages teachers to actively participate in teacher training sessions, and ultimately helps teachers to improve their teaching.

The principal encourages students to participate in co-curricular activities and provides a conducive learning environment to students

The principal focuses to improve the overall learning environment of the school

\section{RESEARCH OBJECTIVES}

1. To evaluate the academic performance of school principals.

2. Investigating the personality traits of emotional stability and neuroticism of secondary school principals.

3. To find out the significant difference between the performance of emotionally stable and neurotic principals

\section{RESEARCH QUESTIONS}

1. How do the secondary school principals identify as emotionally stable/neurotic based on their personality traits?

2. What is the correlation between emotionally stable secondary school principals and their academic performance?

3. Is there any significant difference between the academic performance of emotionally stable and neurotic secondary school principals?

\section{RESEARCH METHODOLOGY}

This research was co relational as it aimed to explore the correlation between emotionally stable secondary school principals and their academic performance. Here the academic performance was taken as a criterion variable whereas the personality trait of emotional stability was considered as a predictor variable. The study followed a positivist paradigm and adopted a quantitative research design, for data collection 
and analysis. This design helps the researchers in data collection by using a questionnaire provided to a selected sample of a target population. This study also discussed the concepts of personality traits and the performance of secondary school principals. So this was descriptive by nature.

\section{Population \& Sampling}

The total population consisted of 32 secondary school principals and 471 teachers of FGEIs (Lahore and Gujranwala Regions). A random sampling technique was adopted to select the sample of the teachers and it consisted of 32 secondary school principals and 238 teachers. The following table 2 shows the total population and selected sample.

Table 1: Population\& Sample selected from the FGEI's Lahore and Gujranwala regions

\begin{tabular}{lllllll}
\hline Region & $\begin{array}{l}\text { Total } \\
\text { Schools }\end{array}$ & $\begin{array}{l}\text { Selected } \\
\text { Schools }\end{array}$ & $\begin{array}{l}\text { Total } \\
\text { Principals }\end{array}$ & $\begin{array}{l}\text { Selected } \\
\text { Principals }\end{array}$ & $\begin{array}{l}\text { Total } \\
\text { Teachers }\end{array}$ & $\begin{array}{l}\text { Selected } \\
\text { Teachers }\end{array}$ \\
\hline Gujranwala & 15 & 15 & 15 & 15 & 241 & 120 \\
Lahore & 17 & 17 & 17 & 17 & 230 & 118 \\
Total & 32 & 32 & 32 & 32 & 471 & 238 \\
\hline
\end{tabular}

\section{Instrument}

A demographic information form was included in the research instruments to collect information like gender, academic qualification, work experience, and school size from the respondents. The respondents included both principals and teachers of the selected sample. Eysenck Personality Inventory (EPI) was deployed to collect information about the personality traits of the secondary school principals. It helped to identify the principals as emotionally stable or neurotic. This questionnaire was filled in by the principals. To collect information regarding the academic performance of school principals an adapted questionnaire of Stronge (2011) was deployed. It was filled in by the teachers.

\section{Validation of the Research Instrument}

For the checking of the validity of the research instruments, a pilot study was conducted. Both of the instruments were administered to 15 principals and 85 teachers. The respondents mentioned no difficulty in understanding all the items. Moreover, they highlighted that all the items were comprehensive. For the calculation of internal reliability of the EPI and academic performance dimension of the second questionnaire, Cronbach's Alpha was used. The reliability of the EPI and academic performance dimension of the second questionnaire is given in the tables 3. Both of the research instruments were also further validated independently by the experts. 


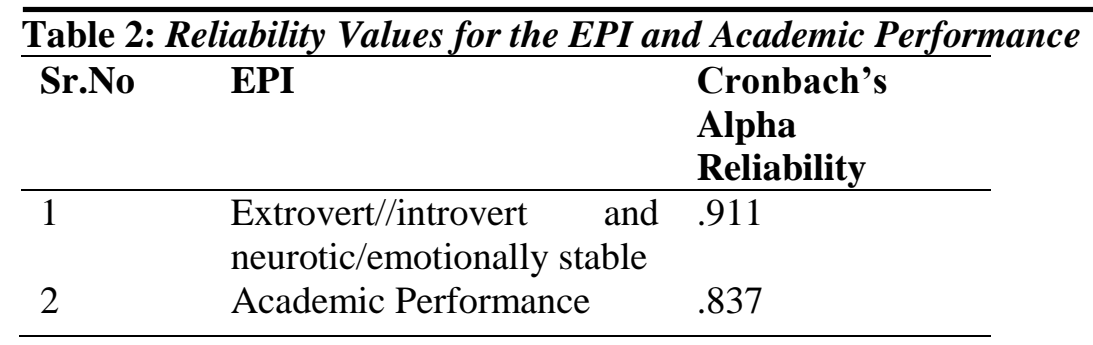

\section{Data Collection Procedure}

Data collection was done by deploying the survey method. This method helped the researchers to collect the primary data of the study. Demographic information form and the research instruments were sent to the principals and teachers of selected FGEIs of Lahore and Gujranwala regions through registered mail. To attain a maximum response, the respondents were repeatedly requested.

\section{DATA ANALYSIS AND RESULTS}

For data analysis, Statistical Packages for the Social Scientists (SPSS) version 21.0 was deployed. This program helped the researchers to calculate descriptive and inferential statistics. Percentages and related figures were obtained through descriptive statistics. To determine correlation and significant difference inferential statistics were used. Pearson Correlation $r$ and t-test were deployed for this purpose.

\section{Descriptive Statistics}

\section{Demographic Information of the Respondents}

i. Out of a total of 32 secondary school principals, 11 were male while 21 were female.

ii. Out of a total of 238 secondary school teachers, 89 were male while 149 were female.

iii. Out of a total of 32 secondary school principals, 20 were M.A, 9 were M.Sc. and 3 were M.Phil.

iv. Out of a total of 238 secondary school teachers, 140 were M.A, 57 were M.Sc., 39 were BS, and 2 were M.Phil.

v. Out of a total of 32 secondary schools, 6 schools were having less than 500 students, 18 schools were having greater than 500 but less than 1000 students and 8 schools were having greater than 1000 students.

vi. Out of a total of 32 secondary school principals, 4 were having work experience between 1 to 3 years, 21 were having work experience between 4 to 10 years and 7 were having experience greater than 10 years.

vii. Out of a total of 238 secondary school teachers, 112 were having work experience between 1 to 3 years, 102 were having work experience between 4 to 10 years and 24 were having work experience greater than 10 years. 


\section{Research Question 1}

How do the secondary school principals identify as emotionally stable/ neurotic based on their personality traits?

The Eysenck's Personality Inventory (EPI) was used to classify secondary school principals as emotionally stable or neurotic based on their personality.

Table 3: Identification of secondary school principals as extrovert and introvert

\begin{tabular}{ccc}
\hline Sr No & $\begin{array}{c}\text { Personality } \\
\text { Trait }\end{array}$ & $\begin{array}{c}\text { Number of } \\
\text { Participants }\end{array}$ \\
\hline O1 & neurotic & 14 \\
02 & emotionally stable & 18 \\
\hline
\end{tabular}

Table 4 shows the classification of principals based on their personality traits. It reveals that 18 heads were emotionally stable and 14 were neurotic.

\section{Description of Performance of Emotionally Stable and Neurotic Secondary School Principals}

i. According to respondents, $81 \%$ of emotionally stable and $19 \%$ of neurotic principals provided learning material to the teachers.

ii. According to respondents, $75 \%$ of emotionally stable and $25 \%$ of neurotic principals ensured the availability of sufficient teaching faculty in their schools.

iii. According to respondents $72 \%$ of emotionally stable and $28 \%$ of neurotic principals guided teachers to prepare a lesson plan.

iv. According to respondents, 55\% of emotionally stable and $45 \%$ of neurotic principals made frequent classroom visits to observe the teaching-learning process and the level of attainment of students.

v. According to respondents $57 \%$ of emotionally stable and $43 \%$ of neurotic principals encouraged students to work hard.

vi. According to respondents $74 \%$ of emotionally stable and $26 \%$ of neurotic principals closely monitored the academic progress of students.

vii. According to respondents $68 \%$ of emotionally stable and $32 \%$ of neurotic principals guided teachers about modern teaching techniques.

viii. According to respondents $70 \%$ of emotionally stable and $30 \%$ of neurotic principals encouraged teachers to attend a teacher training session.

ix. According to respondents, $78 \%$ of emotionally stable and $22 \%$ of neurotic principals helped teachers to improve their teaching.

x. According to respondents, $77 \%$ of emotionally stable and $23 \%$ of neurotic principals encouraged the students to participate in co-curricular activities.

xi. According to respondents $79 \%$ of emotionally stable and $21 \%$ of neurotic principals provided a conducive learning environment to students. 
xii. According to respondents, $72 \%$ of emotionally stable and $28 \%$ of neurotic principals focused to improve the overall learning environment of the school.

\section{Inferential Statistics}

\section{Research Question 2}

What is the correlation between emotionally stable secondary school principals and their academic performance?

Table 4: Correlation coefficients for Emotional Stability Scores and Academic Performance

\begin{tabular}{lcc}
\hline Correlation coefficient & \multicolumn{2}{c}{ Academic Performance } \\
\hline Emotional Stability Scores & $\mathrm{r}$ & $\mathrm{p}$ \\
& .729 & .006 \\
\hline
\end{tabular}

This can be seen in Table 5 shows that emotionally stable secondary school principals are positively correlated with their academic performance. Here r=.729 with the $\mathrm{p}=.006$.

\section{Research Question 3}

Is there any significant difference between the academic performance of emotionally stable and neurotic secondary school principals?

Table 6: Comparison of the academic performance of emotionally stable/ neurotic secondary school principals

\begin{tabular}{|c|c|c|c|c|c|c|}
\hline \multirow[t]{2}{*}{$\begin{array}{c}\text { Performance } \\
\text { Dimension }\end{array}$} & \multicolumn{2}{|c|}{$\begin{array}{c}\text { Emotional } \\
\text { Stability }\end{array}$} & \multicolumn{2}{|c|}{ Neuroticism } & \multirow[b]{2}{*}{$\mathrm{T}$} & \multirow{2}{*}{$\mathrm{P}$} \\
\hline & Mean & S.D & Mean & S.D & & \\
\hline Academic Performance & 53.61 & 4.01 & 21.84 & 2.91 & 3.11 & .004 \\
\hline
\end{tabular}

In table 6, this can be seen that the emotionally stable secondary school principals have a mean score of 53.61 with $\mathrm{SD}=4.01$ whereas neurotic principals have a mean score of 21.84 with $\mathrm{SD}=2.91$. Furthermore $\mathrm{t}=3.11$ for $\mathrm{p}=.004$, which shows that there exists a significant difference in academic performance of emotionally stable and neurotic secondary school principals.

\section{SUMMARY}

The study included 11 male and 21 female secondary school principals. Moreover, there were 89 male and 149 female teachers as respondents.

There were 20 secondary school principals with educational qualifications equal M.A., 9 with M.Sc. and 3 with M.Phil. Similarly, the study included 140 teachers 
with educational qualifications equal to M.A., 57 with M.Sc., 39 with BS, and 2 with M.Phil.

The study was conducted in 6 schools having less than 500 students, 18 schools having greater than 500 but less than 1000 students, and 8 schools having greater than 1000 students.

There were 4 secondary school principals having work experience between 1 to 3 years, 21 having work experience between 4 to 10 years, and 7 having experience greater than 10 years. Similarly, 112 teachers were having work experience between 1 to 3 years, 102 having work experience between 4 to 10 years, and 24 having work experience greater than 10 years, were the respondents of the study.

Out of a total of 32 secondary school principals, 18 were identified as emotionally stable and14 as neurotic.

The majority of neurotic principals failed to provide learning materials to their teachers and a conducive learning environment to their students. However, they made frequent classroom visits and encouraged students to work hard.

On the other hand, the majority of emotionally stable principals succeeded to make sufficient faculty available in their schools, guided teachers in the preparation of lesson plan, closely monitored the academic progress of students, guided the teachers about modern teaching techniques, encouraged the teachers to attend teacher training sessions, encouraged the students to participate in co-curricular activities and focused to improve the overall learning environment of the school.

The academic performance of emotionally stable secondary school principals is positively correlated with each other.

A significant difference exists in the academic performance of emotionally stable and neurotic secondary school principals

\section{DISCUSSION}

The present study followed a positivist paradigm and adopted a co-relational research design and was descriptive. A survey method was deployed for data collection. The demographic information form and the research instruments were sent to the respondents through registered mail. SPSS version 21.0 was deployed for data analysis. Percentages and related figures were obtained. Pearson Correlation $\mathrm{r}$ and $\mathrm{t}-$ test were deployed for inferential statistics of data. Based on data analysis, the following are brief findings of this study. Neurotic principals did not have had an interest in providing learning materials to their teachers and a conducive learning environment to their students. However, they showed a bit of interest in frequent classroom visits. They also tried to encourage students to work hard. Emotionally stable principals showed maximum interest in providing sufficient faculty available in their schools. They also closely monitored the academic progress of students and encouraged the teachers to attend teacher training sessions. They focused to improve the overall learning environment of the school. 
There exists a positive correlation between academic performance and emotionally stable secondary school principals. There exists a significant difference in the academic performance of emotionally stable and neurotic secondary school principals. This study concluded that neurotic principals show less interest in school affairs. They do not provide a conducive learning environment to students. They do not properly guide the teachers to improve their professional capabilities. They do not focus to improve the overall learning environment of the school. The emotionally stable principals perform their duties well as compared to the neurotic principals. They closely monitor the progress of students and help the teachers to improve professional skills. They keep on working to improve the overall learning environment of the school. The academic performance of secondary school principals has a positive correlation with the personality trait of emotional stability and a significant difference can be seen in the performance of emotionally stable and neurotic secondary school principals.

\section{RECOMMENDATIONS}

The present study recommends that secondary school principals should be provided proper awareness about performance indicators and standards of school principals. Neurotic principals should be provided necessary psychological and moral support to reduce this shortcoming of personality. They should be encouraged to adopt the personality trait of emotional stability. This could be helpful to improve their performance as a principal. Future researchers may study other dimensions of performance like human relationships and managerial performance. A comparative study between public and private sector school principals may also be conducted.

\section{REFERENCES}

Adams, J. S. (2003). Wage inequities, productivity and work quality. Industrial Relations: A Journal of Economy and Society, 3(1), 9-16.

Bamburg, J. D., \& Andrews, R. L. (2001). School goals, principals, and achievement. School Effectiveness and School Improvement, 2, 175-191.

Brewer, D. J. (2003). Principals and student outcomes: Evidence from US high schools. Economics of Education Review, 12(4), 281-292.

Catano, N., \& Stronge, J. H. (2011). What are principals expected to do? Congruence between principal evaluation and performance standards. NASSP bulletin, 90(3), 221-237.

Cherns, A. (2006). The principles of sociotechnical design. Human relations, 29(8), 783-792.

Child, I. L., \& Iwao, S. (2008). Personality and esthetic sensitivity: Extension of findings to younger age and to different culture. Journal of personality and social psychology, 8(3p1), 308.

Clark, D., Martorell, P., \& Rockoff, J. (2009). School Principals and School Performance. Working Paper 38. National Center for Analysis of longitudinal data in Education 
research.

Digman, J. M. (2010). Personality structure: Emergence of the five-factor model. Annual review of psychology, 41(1), 417-440.

Griffith, J. (2004), Relation of principal transformational leadership to school staff job satisfaction, staff turnover, and school performance. Journal of Educational Administration, 42(3), 333-356.

Gurr, D., Drysdale, L., \& Mulford, B. (2005). Successful principal leadership: Australian case studies. Journal of Educational Administration, 43(6), 539-551.

Guzzo, R. A., Jette, R. D., \& Katzell, R. A. (2005). The effects of psychologically based intervention programs on worker productivity: A meta-analysis. Personnel Psychology, 38(2), 275-291.

Hallinger, P, and Heck. R. H. (February, 2007). Reassessing the principal's role in school effectiveness: A review of empirical research, 1980-1995. Educational Administration Quarterly, 32(1), 5-44.

Hallinger, P., Brickman, L., \& Davis, K. (2009). School context, principal leadership, and student reading achievement. The Elementary School Journal, 96(5), 527-549.

Hattie, J. (2009). Visible learning: A synthesis of over 800 meta-analyses related to student achievement. New York, NY: Routledge.

Heck, R. H. (2000). Examining the impact of school quality on school outcomes and improvement: A value-added approach. Educational Administration Quarterly, 36(4), 513-552.

Kark, R., Shamir, B., Chen, G. (2003) The Two Faces of Transformational Leadership: Empowerment and Dependency. Journal of Applied Psychology, 88(2), 255-296.

Kernberg, O. F. (2002). Technical considerations in the treatment of borderline personality organization. Journal of the American Psychoanalytic Association, 24(4), 795-829.

Leithwood, K., Jantzi, D., Earl, L., Watson, N., Levin, B., \& Fullan, M. (2004). Strategic leadership for large-scale reform: the case of England's national literacy and numeracy strategy. School Leadership \& Management, 24(1), 57-79.

Nazem, F.(2005).The anticipating of effective leadership through organizational climate and principals' personality characteristics, Journal knowledge and research in psychology. Islamic Azad university of Khurasgan,

Oyewole, B. K., \& Alonge, H. O. (2013). Principals’ Instructional Supervisory Role Performance and Teachers' Motivation in Ekiti Central Senatorial District of Ekiti State, Nigeria. Journal of Educational and Social Research, 3(2), 295.

Peterson, K. D. (2005). Mechanisms of culture building and principal are work. Education and Urban Society. 20, 250-261.

Vatur, J. (2001). A study of relationship between principals' personality characteristics and environmental conditions and their administrative performance in schools. The thesis of M. A. Islamic Azad university of Khurasgan.

Wall, T. D., \& Clegg, C. (2005). A longitudinal field study of group work redesig. Journal of Organizational Behavior, 2(1), 31-49.

Wright, J. S., \& Panksepp, J. (2012). An evolutionary framework to understand foraging, 
PJER, Vol 4, Issue 3 (2021)

Academic performance of... wanting, and desire: the neuropsychology of the SEEKING system. Neuropsychoanalysis, 14(1), 5-39. 